\title{
Oppfølging og behandling etter selvpåført forgiftning
}

\section{Av Tine K. Grimholt}




\section{SAMMENDRAG}

Introduksjon: En betydelig andel pasienter innlegges årlig i sykehus med selvpåført forgiftning og prognosene er alvorlige. Få studier har undersøkt pasientenes egen vurdering av sine problemer og psykiske symptomer i perioden etter utskrivelse.

Det er viktig å sørge for oppfølging etter utskrivelse. I tillegg er det avgjørende at helsepersonell som pasientene møter i behandlingskjeden har god kompetanse. Hittil har vi hatt begrenset kunnskap på disse områdene, som begge er viktige for å kunne gi pasienter et godt helsetilbud.

Hensikt: Hensikten med studien var å undersøke om pasienter innlagt i somatisk avdeling med selvpåført forgiftning fikk tilbud om oppfølging etter utskrivelse og i hvilken grad de vurderte sine egne psykiske symptomer og behov for helsehjelp. I tillegg ønsket vi å undersøke legers egenvurderte kompetanse til å behandle pasienter med selvmordsatferd.

Metoder og materiale: Vi sendte et spørreskjema til alle pasienter som ble innlagt med selvpåført forgiftning ved akuttmedisinske avdelinger i Oslo og Bærum i løpet av et år $(n=867)$. Vi undersøkte i hvilken grad de fikk tilbud om oppfølging, tilfredshet med behandlingen de fikk og i hvilken grad de hadde psykiske symptomer og behov for helsetjenester tre måneder etter utskrivelse. I en spørreundersøkelse av et tilfeldig utvalg norske leger i allmennmedisin, psykiatri og indremedisin $(n=750)$ undersøkte vi deres egenvurderte kompetanse og holdninger til pasienter med selvmordsatferd, og deres interesse for kurs og undervisning.

Resultater: Det var $14 \%$ som var registrert uten oppfølging i sykehusets journal, men 41 \% svarte at de ikke hadde fått noe tilbud. Mer enn én av fire (29 \%) måtte vente i mer enn tre uker. Pasientene oppgav moderate til alvorlige symptomer på depresjon, og håpløshet og redusert evne til egenmestring. Nær én av fire hadde forgiftet seg på nytt. Pasientene var i hovedsak tilfredse med behandlingen de hadde fått, bortsett fra de som fikk behandling for rusproblemer. Om lag alle oppgav behov for mer helsehjelp. Legenes egenvurderte kompetanse var god. Holdningene til pasienter med selvmordsatferd var positive i form av forståelse, interesse og ønske om å hjelpe, imidlertid fikk pasienter med rusmisbruk lavere empatiskåre, sammenliknet med andre diagnoser. Det var 43 \% som hadde deltatt på kurs eller andre former for utdanning om vurdering og behandling av pasienter med selvmordsatferd siste fem år, og psykiatere var mest interessert i kurs.

Konklusjon: Pasienter som innlegges i somatisk sykehus etter selvpåført forgiftning fikk ikke tilstrekkelig oppfølging og behandling ved utskrivelse, og hadde høy grad av psykiske symptomer og ønsket mer helsehjelp. Legenes egenvurderte kompetanse og holdninger til å behandle pasienter med selvmordsatferd var god, men over halvparten hadde ikke deltatt på kurs.

\section{ABSTRACT}

Introduction: A considerable number of patients are admitted to somatic hospitals with deliberate self-poisoning each year, and the prognoses are serious. However, knowledge is sparse about the patient's self-perceived problems and psychiatric symptoms post discharge. It is important to provide adequate health care services to this patient group and it is important that health care personnel have positive attitudes and sufficient competence.

Objectives: The objectives of the study were to examine whether patients hospitalized for self-poisoning received follow-up after discharge, as well as the patients' assessments of their own psychological symptoms and need for health care services. Furthermore, we aimed to study physicians self-perceived competence to treat patients with suicidal behaviour and their participation and interest in theoretical training.

Method and materials: All patients that were admitted to somatic hospitals in Oslo and Bærum County during one year $(n=867)$ received a questionnaire about follow-ups, satisfaction, psychiatric symptoms, and self-perceived need for health care services three months after discharge. In a survey of a random sample of Norwegian general practitioners, psychiatrists, and internists $(n=750)$, their attitudes and self-perceived competence to treat patients with suicidal behaviour together with participation and interest in courses were studied.

Results: We found a discrepancy between registered follow-ups at the time of discharge in the hospital records $(86 \%)$ and self-reports from the patients (59\%). $29 \%$ of the patients waited more than three weeks for their first appointment. The patients had moderate to severe symptoms of depression and hopelessness, and low self-efficacy, and $22 \%$ had poisoned themselves again. The patients were satisfied with the treatment, except from drug misuse treatment. The vast majority reported a need for health care services. The physicians' self-perceived competence was good, and the attitudes were positive. $43 \%$ had participated in theoretical training

Conclusion: Patients hospitalized for self-poisoning did not receive sufficient follow-up care post discharge. The levels of problems were considerable and they needed further health care services. The physicians perceived their competences to be good and they had positive attitudes towards patients with suicidal behaviour. 


\section{Bakgrunn}

Årlig innlegges en betydelig andel pasienter i medisinske avdelinger i Norge på grunn av selvpåført forgiftning (Kopiar, Dieserud, \& Wiik, 2005). Spesielt er andelen med risikofaktorer for selvmordsatferd, som tidligere selvmordsforsøk og rusmisbruk, høy i denne pasientgruppen (Bjornaas et al., 2010). I løpet av det første året er det mange som re-innlegges med rusrelaterte forgiftninger og nye selvmordsforsøk (Heyerdahl et al., 20o9). Både kort- og langtidsprognosene er alvorlige, og det er en betydelig risiko for død av selvmord, men også av naturlige årsaker (Bergen et al., 2012; Bjornaas, Jacobsen, Haldorsen, \& Ekeberg, 2009). Tilstrekkelig oppfølging og behandling av denne pasientgruppen etter utskrivelse fra sykehus er derfor viktig. For å kunne tilby dette er blant annet helsepersonells kompetanse og engasjement avgiørende. En sammenstilling av flere internasionale studier har vist at helsepersonells holdninger i stor grad varierer når det gielder grad av interesse og forståelse for selvmordstruede pasienter og dette vil også i noe grad gienspeiles i pasientenes tilfredshet med den behandlingen de har mottatt i helsevesenet (Taylor, Hawton, Fortune, \& Kapur, 2009). I denne artikkelen belyses faktorer omkring behandlingstilbudet til selvmordstruede pasienter ved å oppsummere resultater fra to tidligere publiserte norske studier (Grimholt, Bjornaas, Jacobsen, Dieserud, \& Ekeberg, 2012; Grimholt, Haavet, Jacobsen, Sandvik, \& Ekeberg, 2014).

\section{Metoder og materiale}

Alle pasienter som ble innlagt med selvpåført forgiftning ( $n=867)$ ble i løpet av ett år (perioden 2003-04) prospektivt registrert ved Bærum sykehus og alle sykehusene i Oslo. Studien ble godkjent av Regional Etisk Komite. Behandlende lege ved sykehuset registrerte bakgrunnsvariabler og om det var planlagt videre oppfølging etter utskrivelse på et eget skjema. Pasientene fikk et spørreskjema i posten tre måneder etter utskrivelse. Spørsmålene handlet om oppfølging og behandling, tilfredshet med ulike deler av behandlingskjeden og egenvurdert behov for helsetjenester etter utskrivelse fra sykehuset. For å kartlegge symptomer på depresion og håpløshet brukte vi Beck Depression Inventory (BDI) og Beck Hopelessness Scale (BHS) (Beck, Steer, Beck, \& Newman, 1993; Beck, Weissman, Lester, \& Trexler, 1974). For å måle grad av egenmestring brukte vi General Self-Efficacy skala. Det er et instrument som måler grad av tro på egen evne til å mestre vanskelige situasjoner og takle variasjoner av stressende faktorer (Schwarzer, 1993).

Svarandelen var $28 \%(n=242)$. Giennomsnittsalderen var 41 år og 66 \% var kvinner. Som vist i tabell 1, var det få signifikante forskjeller i gruppen som svarte sammenliknet med gruppen som ikke svarte, men det var flere menn og pasienter med daglig rusmisbruk som ikke svarte.
Tabell 1 Karakteristika i utvalget pasienter behandlet for selvpåført forgiftning (sammenliknet med de som ikke svarte)

\begin{tabular}{|l|c|c|c|}
\hline & $\begin{array}{c}\text { Svarte } \\
\text { (n = 242) }\end{array}$ & $\begin{array}{c}\text { Svarte } \\
\text { ikke } \\
\text { (n=622) }\end{array}$ & P-verdi \\
\hline Gjennomsnittsalder & 40.8 år & 40.4 år & 0.746 \\
\hline Kvinner & $66 \%$ & $56 \%$ & 0.007 \\
\hline Aleneboende & $42 \%$ & $40 \%$ & 0.605 \\
\hline I arbeid/studier & $19 \%$ & $19 \%$ & 0.887 \\
\hline Intensjon & & & 0.382 \\
\hline Mulig / sikkert selvmordsforsøk & $42 \%$ & $38 \%$ & \\
\hline Usikkert om selvmordsforsøk & $27 \%$ & $26 \%$ & \\
\hline Rusrelatert forgiftning & $31 \%$ & $36 \%$ & \\
\hline Tidligere selvmordsforsøk & $44 \%$ & $50 \%$ & 0.087 \\
\hline $\begin{array}{l}\text { Pågående behandling i psy- } \\
\text { kiske helsetjenester }\end{array}$ & $42 \%$ & $40 \%$ & 0.744 \\
\hline $\begin{array}{l}\text { Tidligere behandling psykiske } \\
\text { helsetjenester }\end{array}$ & $44 \%$ & $50 \%$ & 0.087 \\
\hline Daglig rusmisbruk & $27 \%$ & $39 \%$ & 0.003 \\
\hline
\end{tabular}

Dataene brukt til sammenlikning fra gruppen som ikke svarte på denne etterundersøkelsen er de samme som er publisert i tidligere studier, hvor pasientene allerede har samtykket til å delta.(Bjornaas et al., 2010)

For å undersøke egenvurdert kompetanse og holdninger til pasienter med selvmordsatferd, sendte vi et spørreskjema til et tilfeldig utvalg av alle registrerte norske leger i allmennpraksis, indremedisin og psykiatri $(n=750)$. Studien ble godkjent av Personvernombudet ved Oslo Universitetssykehus og dataene ble behandlet, avidentifisert og lagret i tråd med gieldende retningslinjer. Kiønn, aldersgruppe og ansiennitet ble registrert. I tillegg spurte vi om erfart selvmord hos egen pasient (ja/nei). Egenvurdert kompetanse til å behandle, engasjement, irritasjon og empati ble sammenliknet ved ulike diagnoser; somatiske sykdommer (kreft, diabetes, hjerte- og infeksjonssykdommer), psykiske lidelser (angstlidelser og depresion), suicidal atferd og rusmisbruk (misbruk av alkohol, opiater, A- og B-preparater). Holdninger ble målt med Understanding of Suicidal Patients Scale (USP), som tidligere er blitt benyttet i tilsvarende studier i andre skandinaviske land (Samuelsson, Asberg, \& Gustavsson, 1997; Suokas, Suominen, \& Lonnqvist, 2008). Skalaen har elleve spørsmål som handler om grad av forståelse og vilje til å møte og behandle pasienter etter et selvmordsforsøk med en sumskåre fra 11 (positive holdninger) til 55 (negative holdninger). I en tidligere studie ble en skåre lavere enn 23 og en skåre fra 33 og høyere satt som cut-off for henholdsvis positive og negative holdninger (Suominen, Suokas, \& Lonnqvist, 2007).

Spørsmål om interesse for og tidligere deltakelse på kurs ble lagt til: "Har du deltatt på kurs eller opplæring i vurdering og behandling av pasienter med selvmordsatferd siste fem år?" (Ja/nei). "I hvilken grad er du interessert i kurs og opplæring innenfor suicidologi?" ( $1=$ ikke i det hele tatt til $5=$ i meget høy grad). Det var $40 \%(n=300)$ som svarte etter tre purringer. Det var ikke signifikant forskjell med hensyn til svarandel mellom de tre spesialitetene. Som vist i tabell 2, var det signifikant flere kvin- 
ner i psykiatrigruppen i tillegg til at indremedisinerne var yngre. Flere leger i allmennmedisin og psykiatri hadde erfart selvmord hos egen pasient sammenliknet med leger $\mathrm{i}$ indremedisin (tabell 2).

Tabell 2 Karakteristika i utvalget; Spesialitet, kjønn, erfaring, alder og erfart selvmord hos egen pasient $(n=300)$

\begin{tabular}{|c|c|c|c|c|}
\hline & Allmennpraksis & Psykiatri & Indremedisin & p-verdi \\
\hline $\mathrm{N}=300 / 750$ & 250 & 250 & 250 & \\
\hline & n (\%) & n (\%) & n (\%) & \\
\hline & $91(36)$ & $102(41)$ & $107(43)$ & \\
\hline Kvinner & 31 (34) & $48(47)$ & $30(28)$ & 0.015 \\
\hline \multicolumn{5}{|l|}{ Erfaring (År) } \\
\hline $0-5$ & $4(4)$ & $7(7)$ & $29(27)$ & \\
\hline $6-10$ & $11(12)$ & $14(14)$ & $16(15)$ & \\
\hline $11-20$ & $25(28)$ & $29(28)$ & $20(19)$ & \\
\hline $21-30$ & $30(33)$ & $25(25)$ & $21(20)$ & \\
\hline$>30$ & $19(21)$ & $27(27)$ & $21(20)$ & $<0.001$ \\
\hline Ikke svart & $2(2)$ & & & \\
\hline \multicolumn{5}{|l|}{$\begin{array}{l}\text { Aldersgrupper } \\
\text { (År) }\end{array}$} \\
\hline$<30$ & $\begin{array}{ll}- \\
-\end{array}$ & - & $12(11)$ & \\
\hline $30-40$ & $16(18)$ & $26(26)$ & $37(35)$ & \\
\hline $41-50$ & $28(31)$ & $26(26)$ & $22(21)$ & \\
\hline $51-60$ & 35 (39) & $25(25)$ & $24(22)$ & \\
\hline$>60$ & $12(13)$ & $24(24)$ & $12(11)$ & $<0.001$ \\
\hline Ikke svart & - & $1(1)$ & - & \\
\hline $\begin{array}{l}\text { Erfart selvmord } \\
\text { pasient }\end{array}$ & $68(75)$ & 73 (72) & $38(36)$ & $<0.001$ \\
\hline
\end{tabular}

\section{Statistiske metoder}

Dataene er presentert med giennomsnittsverdier og $95 \%$ konfidensintervaller (KI). For å sammenlikne mellom grupper brukte vi chi-square test (x2) for kategoriske variabler, og Students t-test og ANOVA for kontinuerlige normalfordelte data. $\mathrm{P}<0.05$ ble ansett som signifikant. Data ble analysert med SPSS v .15.0 \& 18 (IBM, Armonk, NY, USA).

\section{Resultater}

\section{Oppfølging og behandling}

På sykehuset var 14 \% registrert uten oppfølging, allikevel svarte $41 \%$ at de ikke hadde fătt noen form for tilbud om oppfølging ved utskrivelse. Det var $29 \%$ som svarte at de måtte vente i tre uker eller lengre til forste avtale for behandling og oppfølging. De fleste pasientene (34\%) ble henvist til distriktpsykiatrisk poliklinikk (DPS), psykiatrisk avdeling (23\%) og allmennlege (23\%). Blant de som svarte at de ikke fikk oppfølging var vanligste registrerte henvisning på sykehuset allmennlege og DPS i henholdsvis 28 og $26 \%$ av tilfellene.

\section{Tilfredshet}

Som vist i tabell 3, var pasientenes tilfredshet med behandlingen i hovedsak god. Høyest skåre fikk den generelle behandlingen på sykehuset. Pasientene var imidlertid mindre fornøyd med planer for oppfølging ved utskrivelse og minst fornøyd med poliklinisk rusbehandling og familieterapi.
Tabell 3 Tilfredshet med behandling og oppfølging

\begin{tabular}{|l|c|c|c|}
\hline & $\mathbf{n}$ & Gj.Snitt & $\mathbf{9 5 \%} \mathbf{~ K} \mathbf{~}$ \\
\hline $\begin{array}{l}\text { Skala: } \\
\text { 1= Svært misfornøyd } \\
\text { 5=Svært fornøyd }\end{array}$ & & & \\
\hline Medisinsk sykehusavdeling & & & \\
\hline Generell behandling & 227 & 3.9 & $3.7-4.1$ \\
\hline Kontakt med sykepleiere & 236 & 3.8 & $3.6-4.0$ \\
\hline Kontakt med lege & 227 & 3.3 & $3.1-3.5$ \\
\hline Kontakt med sosionom & 94 & 3.3 & $3.0-3.6$ \\
\hline Konsultasjon med psykiater & 140 & 3.0 & $2.8-3.3$ \\
\hline $\begin{array}{l}\text { Planer for oppfølging ved } \\
\text { utskrivelse }\end{array}$ & 146 & 2.9 & $2.7-3.1$ \\
\hline Helsetjenester etter utskrivelse & & & 3.9 \\
\hline Psykiatrisk døgnavdeling & 84 & 3.6 & $3.3-3.8$ \\
\hline Psykiatrisk poliklinikk & 42 & 3.3 & $2.8-3.7$ \\
\hline Fastlege & 41 & 3.4 & $2.9-3.9$ \\
\hline Selvmordsforebyggende team & 29 & 3.2 & $2.6-3.8$ \\
\hline Privat psykolog/psykiater & 25 & 2.9 & $2.2-3.6$ \\
\hline Poliklinisk rusbehandling & 12 & 2.2 & $1.1-3.2$ \\
\hline Familieterapi & 13 & 2.2 & $1.2-3.2$ \\
\hline
\end{tabular}

Ikke alle kategorier var aktuelle for alle pasientene, derfor varierer svarandelen (n) i denne tabellen.

Figur 1 Andel pasienter fordelt på høyeste nivå av egen vurdert behov for helsetjenester for ulike helseproblemer totalt

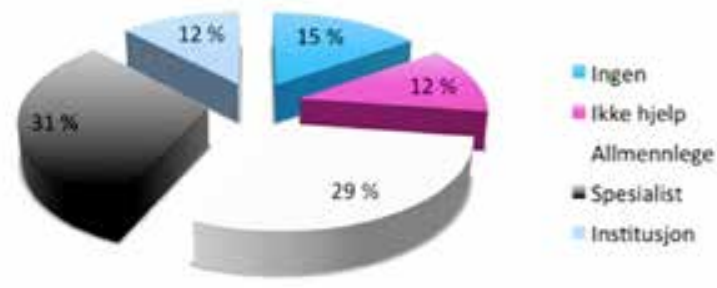

\section{Behov for helsetjenester}

Figur 1 viser at den totale andelen som oppgav behov for hjelp var betydelig. Om lag en av ti svarte at de hadde behov for innleggelse i institusjon, $31 \%$ hjelp fra spesialisthelsetjeneste og $29 \%$ fra allmennlege (Figur 1). I hovedsak var disse behovene knyttet til depresion og angst, men også til rusmisbruk og smerteproblematikk.

\section{Psykiske symptomer og repetert selvskading}

Gjennomsnittlig skåre på BDI og BHS var henholdsvis 23.3 (95\% KI 21.5-25.1) og 10.1 (95\% KI 9.7-11.0). Dette indikerer moderate til alvorlige og behandlingstrengende nivåer. General Self-Efficacy skåre var 25.2 (95 \% KI 24.2-26.1), og tyder på nokså lav evne til egenmestring.

Det var 22 \% som svarte at de hadde forgiftet seg på nytt, og $17 \%$ at de hadde kuttet seg i lopet av de siste tre månedene etter utskrivelse.

\section{Legenes egenvurderte kompetanse}

Egenvurdert kompetanse fulgte legenes spesialitet; psykiatere vurderte sin egen kompetanse høyest når det gjaldt å behandle pasienter med psykiske lidelser og rus, og tilsvarende vurderte indremedisinere at de hadde høyest 
kompetanse til å behandle somatiske diagnoser (Tabell 4). Allmennlegenes egenvurderte kompetanse lå litt over middelverdiene for alle diagnosene, men lavest for selvmordsatferd.

Samme mønster kunne man se ved engasjement. Når det gialdt empati, var det ingen forskjell mellom spesialitetene med hensyn til deres empati for pasienter med selvmordsatferd og rusmisbruk (Tabell 4). Kvinner var signifikant mer empatiske til pasienter med selvmordsatferd enn menn (4.0 vs. 3.8), også etter at det ble justert for spesialitet, alder og kursdeltakelse $(\mathrm{p}=0.002)$. Pasienter med rusmisbruk fikk lavest empatiskåre i alle tre grupper (2.9-3.2) sammenliknet med de andre diagnosene (Tabell 4). På tilsvarende spørsmål om irritasjon, svarte alle tre gruppene at de var mest irritert på rusmisbrukere sammenliknet med pasienter med andre diagnoser.

Tabell 4 Egenvurdert kompetanse, engasjement og empati ved somatiske diagnoser, rusmisbruk, depresjon og angst og selvmordsatferd $i$ henhold til spesialitet

\begin{tabular}{|l|l|l|l|l|}
\hline & $\begin{array}{c}\text { Allmenn- } \\
\text { leger } \\
\text { Gj. Snitt } \\
\text { (95\% KI) }\end{array}$ & $\begin{array}{c}\text { Psykiatere } \\
\text { Gj. Snitt } \\
\mathbf{( 9 5 \% ~ K I ) ~}\end{array}$ & $\begin{array}{c}\text { Indre- } \\
\text { medisinere } \\
\text { Gj. Snitt } \\
\text { (95\% KI) }\end{array}$ & p-verdi \\
\hline Kompetanse & $3.6(3.5-3.7)$ & $2.3(2.1-2.4)$ & $3.6(3.5-3.7)$ & $<0.001$ \\
\hline $\begin{array}{l}\text { Somatiske } \\
\text { diagnoser }\end{array}$ & $3.3(3.1-3.4)$ & $3.5(3.4-3.6)$ & $2.5(2.4-2.6)$ & $<0.001$ \\
\hline Rusmisbruk & $3.6(3.4-3.7)$ & $4.3(4.2-4.4)$ & $2.5(2.3-2.6)$ & $<0.001$ \\
\hline $\begin{array}{l}\text { Depresjon og } \\
\text { angst }\end{array}$ & $3.2(3.1-3.4)$ & $4.1(4.0-4.2)$ & $2.4(2.3-2.5)$ & $<0.001$ \\
\hline Selvmordsatferd & $3.7(3.6-3.8)$ & $2.3(2.2-2.5)$ & $3.7(3.6-3.8)$ & $<0.001$ \\
\hline $\begin{array}{l}\text { Engasjement } \\
\text { diagnoser }\end{array}$ & $3.4(3.3-3.5)$ & $3.8(3.7-3.9)$ & $2.6(2.5-2.8)$ & $<0.001$ \\
\hline Rusmisbruk & $3.7(3.6-3.8)$ & $4.2(4.1-4.3)$ & $2.7(2.5-2.8)$ & $<0.001$ \\
\hline $\begin{array}{l}\text { Depresjon og } \\
\text { angst }\end{array}$ & $3.6(3.5-3.8)$ & $3.4(3.3-3.5)$ & $3.8(3.7-3.9)$ & $<0.001$ \\
\hline Selvmordsatferd & $3.7(3.5-3.8)$ & $4.2(4.1-4.3)$ & $2.8(2.6-3.0)$ & $<0.001$ \\
\hline & $3.8(3.7-3.9)$ & $3.9(3.8-4.1)$ & $3.5(3.4-3.7)$ & $<0.001$ \\
\hline Empati & $3.9(3.8-4.1)$ & $3.9(3.8-4.1)$ & $3.7(3.6-3.9)$ & 0.076 \\
\hline Somatiske \\
diagnoser
\end{tabular}

Skala: $1=$ veldig lav-5 = veldig høy

\section{Holdninger}

Totalt hadde alle legene positive holdninger til pasienter med selvmordsatferd (USP=20.3, 95\% KI: 19.6-20.9). Blant allmennleger var det signifikant forskjell mellom kvinner og menn (USP 17.7 vs. 20.3, p=0.014). Etter at vi justerte for alder, kiønn, kursdeltakelse og erfart selvmord hos egen pasient, hadde allmennleger og psykiatere signifikant mer positive holdninger sammenliknet med indremedisinere.

Ved å se på de enkelte påstandene i USP-skalaen separat, fant vi at alle gruppene hadde forståelse for at pasienter med selvmordsatferd hadde emosionelle proble- mer og derfor trengte best mulig behandling (1.4, 95\% KI: 1.4-1.5). De var også enig i påstanden "En person som har forsøkt å ta sitt eget liv er en person jeg gierne vil hielpe" (1.5, 95\% KI: 1.4-1.6). Psykiatere (1.7, 95\% KI: 1.6-1.9) var signifikant mer enig $\mathrm{i}$ at pasientene fikk god behandling ved deres avdeling sammenliknet med allmennleger (2.0, 95\% KI: 1.8-2.2) og indremedisinere (2.3, 95\% KI: $2.1-2.5)$ $(\mathrm{p}<0.001)$. Indremedisinerne var mindre enig i påstanden, "Teg forsøker å giøre mitt beste for å snakke med en pasient som har forsøkt å ta sitt liv om hans/hennes personlige problemer" (2.0, 95\% KI: 1.8-2.2) vs. allmennleger (1.5, 95\% KI: 1.3-1.6) og psykiatere (1.4, 95\% KI: 1.2-1.6) (p<0.001). Indremedisinerne syntes også at det var vanskeligere å forstå en person som hadde forsøkt å ta sitt liv ("Jeg synes ofte det er vanskelig å forstå en person som har forsøkt å ta sitt liv") (3.4, 95\% KI: 3.2-3.7) vs. allmennleger (2.8, 95\% KI: 2.6-3.1) og psykiatere $(2.4,95 \%$ KI: 2.2-2.6). Tilsvarende var indremedisinerne mer enig i påstanden "Det er vanligvis vanskelig å møte en person som har forsøkt å ta sitt eget liv" (3.1, 95\% KI: 2.9-3.4) vs. allmennleger (2.5, 95\% KI: 2.2-2.8) og psykiatere (2.4, 95\% KI: 2.1-2.7) (p<0.001).

\section{Kurs og utdanning}

I underkant av halvparten (43\%) hadde deltatt på kurs eller andre former for utdanning om vurdering og behandling av pasienter med selvmordsatferd siste fem år. Psykiatere hadde i større grad deltatt på kurs ( $n=77,76 \%)$ enn allmennleger ( $n=35,39 \%$ ) og indremedisinere $(n=16,15 \%)$. Psykiatere var også mer interessert i kurs sammenliknet med indremedisinerne, på tross av at indremedisinernes egenvurderte behov for mer kunnskap var større.

\section{Diskusjon}

På tross av at oppfølging var registrert ved sykehuset svarte mange pasienter at de ikke fikk noe tilbud etter tre måneder. Andelen med alvorlige psykiske symptomer og selvskadende handlinger understreker at det er behov for mer aktive former for oppfølging og behandling.

Tilfredsheten med behandlingen på sykehuset var i hovedsak god. En betydelig andel hadde alvorlige psykiske problemer, og mange hadde forgiftet og kuttet seg. Norske leger i allmenn-, indremedisin og psykiatri vurderte sin egen kompetanse til å behandle pasienter med selvmordsatferd til å være god. Alle legegruppene var positive, velvillige og forståelsesfulle, og kvinner var mer empatiske enn sine mannlige kollegaer. Pasienter med rusmisbruk var den gruppen som kom dårligst ut sammenliknet med andre pasientgrupper når det gjaldt legenes engasjement, empati og irritasjon.

Diskrepans mellom registrert oppfølging ved sykehuset og pasientenes egne svar ble også vist i en studie fra Nederland, hvor $35 \%$ av pasienter som hadde fors $ø$ kt å ta livet sitt ikke husket om det var giort avtaler for oppfølging da de ble spurt syv dager etter utskrivelse fra sykehuset (Verwey et al., 2010). I vår studie fant vi at en betydelig andel av pasientene måtte vente opp til tre uker for de fikk behandling. I en akutt krise er det mulig at pasienter oppfatter slik ventetid som at de ikke fikk oppfølging og behandling. Andre forklaringer kan være at pasientene ikke husket det, ikke fikk god nok beskjed på sykehuset eller skriftlig informasion. Dette understreker betydningen av å sikre at pasientene får tydelig og skriftlig beskjed 
om planer for oppfølging før de utskrives fra sykehuset. Her vil nok betydningen av holdninger og kompetanse blant leger og sykepleiere være viktig. En stresset klinisk hverdag på sykehuset kan påvirke holdninger i negativ retning (Suokas \& Lonnqvist, 1989), og det er viktig å sette av tid til å lytte til deres erfaringer og behov for hjelp og gi tilstrekkelig grad av informasjon. Spesielt viktig blir grad av positive holdninger som innebærer velvillighet og forståelse, da pasientene ofte er særlig sårbare for avvisning i tillegg til å ha vanskeligheter med å selv søke hielp for sine problemer (Wolk-Wasserman, 1985).

De aller fleste pasientene var tilfredse med behandlingen de fikk på sykehuset, ved psykiatriske døgnavdeling og DPS etter utskrivelse. Dette er gienspeilet i vår studie blant norske leger og i to tilsvarende norske studier av sykepleiere i akuttmedisinske avdelinger og ansatte i DPS som begge viser positive holdninger til pasienter med selvmordsatferd (Grimholt, 2007) (Norheim, Grimholt, \& Ekeberg, 2013). Minst tilfredse var pasientene med planer for oppfølging og ventetiden til første behandlingsavtale. En systematisk litteraturgiennomgang av Taylor og medarbeidere viste også et tydelig behov for bedre tilgiengelighet til oppfølging i denne pasientgruppen (Taylor et al., 2009). Det er per i dag begrenset evidensbasert kunnskap om effektive intervensioner som reduserer ytterligere selvmordsatferd blant pasienter som innlegges i sykehus med selvpåførte forgiftninger (Mehlum et.al., 2008). Med bakgrunn i de komplekse, og ofte sammensatte psykososiale og somatiske problemene som er kjent fra tidligere og understreket i denne studien, er det viktig å tilby et koordinert og skreddersydd oppfølgingstilbud. Funnene i vår studie som viser høy grad av psykiske symptomer og selvskadende atferd underbygger dette.

Det er i tillegg et problem at mange dropper ut eller ikke møter til behandling (Runeson, 2001). I en nyere norsk studie fant vi at $23 \%$ av pasienter innlagt i akuttmedisinske avdelinger hadde latt være å møte til planlagt behandling i løpet av de seks første månedene etter utskrivelse (Grimholt et al., 2015). I den norske Bærumsmodellen viste behandlingskjedetilbud og tidlig intervension etter et selvmordsfors $ø$ k lovende resultater med hensyn til lavere drop out fra behandling (Dieserud, Loeb, \& Ekeberg, 2000). Tilsvarende resultater har man også funnet i liknende studier basert på det samme konseptet (Hvid et al., 2011; Verwey et al., 2010). Dessverre har slike behandlingskjeder bare blitt implementert i varierende grad her til lands og Mork og kollegaer fant at bare halvparten av norske sykehus hadde et system for å koordinere oppfølging, samt at praksis ikke var i tråd med nasjonale anbefalinger (Mork, Mehlum, Fadum, \& Rossow, 2010)

Funnene som viser at legenes kompetanse tenderer til å samsvare med spesialitet er ikke overraskende. Det er allikevel et poeng som er viktig å ta med seg inn i den kliniske hverdagen, fordi sykelighet og dødelighet med bakgrunn i somatisk sykdom og livsstilsfaktorer i denne pasientgruppen er forhøyet (Bergen et al., 2012). I klinisk praksis innebærer det for eksempel at behandlere ved psykiatriske avdelinger som for eksempel DPS også må identifisere livsstilsfaktorer knyttet til helserisiko og vurdere pasientene med tanke på deres somatiske helsetilstand for å forebygge og behandle. Fastlegen har også en viktig rolle for denne pasientgruppen, og et koordinert og

rutinemessig samarbeid mellom spesialisthelsetjenesten og allmennpraksis vil ofte være nødvendig.

Pasientene var minst tilfredse med poliklinisk rusbehandling og legene oppgav lavest kompetanse, engasjement og empati til pasienter med rusmisbruk sammenliknet med pasienter med andre diagnoser. Rusmisbruk er en uavhengig risikofaktor for selvmord blant selvmordsforsøkere (Hawton, Fagg, Platt,

Etter tre måneder hadde en betydelig andel pasienter psykiske problemer og ønsket mer hjelp fra helsevesenet \& Hawkins, 1993), og det er viktig å sørge for at pasienter som sliter med rusproblematikk får tilstrekkelig helsehjelp. Det er ikke mulig å trekke noen slutninger om hvordan disse holdningene arter seg i praksis. Selv om mange oppgir at de blir irriterte på pasienter med rusproblemer i en survey, betyr

det ikke at legene ikke opptrer profesionelt i møte med pasientene. Det er heller ikke mulig å si noe om hvorfor psykiatere vurderer sin kompetanse til å behandle rusmisbrukere lavere, men mulige årsaksmekanismer kan være manglende kunnskap om effektiv behandling og tilsvarende tilbud. En annen forklaring kan være at mange leger på tross av utrettelig engasjement ikke opplever at det hielper i særlig grad.

\section{Begrensninger}

Lav svarandel begrenser funnenes validitet og generaliserbarhet. Allikevel utgiør antallet pasienter som oppgav betydelige helseplager og behov for helsehielp en betydelig andel av det totale utvalget som fikk tilsendt spørreskjema og er således uansett et viktig og robust funn. I tillegg hadde vi anledning til å giennomføre frafallsanslyser som viste at det ikke var betydelige forskieller mellom de pasientene som returnerte spørreskjemaet og de som ikke svarte. Likeledes er sammenlikningene mellom de ulike legespesialitetene pålitelige selv om svarandelen totalt var lavere enn ønskelig. Vi kan derfor ikke generalisere resultatene til å gielde alle norske leger.

\section{Tabell 5 Multivariable sammenlikning av holdninger mellom allmennleger, psykiatere og indremedisinere med Understanding of Suicidal Patients Scale som avhengig variabel}

\begin{tabular}{|l|c|c|c|c|c|c|}
\hline & \multicolumn{3}{|c|}{ Ujustert } & \multicolumn{3}{c|}{ Justert* } \\
\hline & $\beta$ & $95 \% \mathrm{KI}$ & $\mathrm{p}$-verdi & $\beta$ & $95 \% \mathrm{KI}$ & $\mathrm{p}$-verdi \\
\hline $\begin{array}{l}\text { Psykiatere vs. } \\
\text { Allmennleger }\end{array}$ & -0.95 & $\begin{array}{c}-0.4 \text { til } \\
2.3\end{array}$ & 0.18 & -0.6 & $\begin{array}{c}-2.1 \\
\text { til-0.8 }\end{array}$ & 0.393 \\
\hline $\begin{array}{l}\text { Allmennleger vs. } \\
\text { Indremedisinere }\end{array}$ & -3.3 & -4.8 & $<0.001$ & -2.3 & $\begin{array}{c}-4.0 \text { til }- \\
0.6\end{array}$ & 0.009 \\
\hline $\begin{array}{l}\text { Psykiatere vs. } \\
\text { Indremedisinere }\end{array}$ & -4.3 & -5.6 til & $<0.001$ & -3.9 & $\begin{array}{c}-5.8 \text { til } \\
-1.9\end{array}$ & $<0.001$ \\
\hline
\end{tabular}

* Justert for alder, kjønn, kursdeltakelse og erfaring med selvmord hos pasient 


\section{Konklusjon}

På tross av at pasientene var registrert med tilbud om behandling og oppfølging ved utskrivelse fra sykehuset svarte mange at de ikke fikk noe tilbud. Pasientene var i hovedsak tilfredse med behandlingen de fikk, men pasienter som fikk tilbud om poliklinisk rusbehandling var minst tilfredse. Dette reflekteres også i legenes egenvurderte kompetanse, engasjement og empati til pasienter med rusmisbruk. Dette er nok noe man bør undersøke nærmere, spesielt fordi psykiatrisk komorbiditet er vanlig blant rusmisbrukere, i tillegg til en forhøyet risiko for både død av naturlige årsaker og selvmord.

Etter tre måneder hadde en betydelig andel pasienter psykiske problemer og onsket mer hielp fra helsevesenet. Leger i allmenn-, indremedisin og psykiatri oppgir god kompetanse til å behandle pasienter med selvmordsatferd og har positive holdninger. Selv om under halvparten hadde deltatt på kurs eller andre former for videreutdanning siste fem år, var de middels interessert i å delta på kurs. Fremtidig undervisningsopplegg kan nok ha nytte av å kartlegge ulike spesialiteters behov for innhold og varighet når det gielder kurs og kompetanseutvikling innenfor suicidologi.

Denne artikkelen er et sammendrag av to tidligere publiserte artikler:

1) Grimholt, T. K., Bjornaas, M. A., Jacobsen, D., Dieserud, G., \& Ekeberg, O. (2012). Treatment received, satisfaction with health care services, and psychiatric symptoms 3 months after hospitalization for self-poisoning. Ann Gen Psychiatry, 11, 10. doi:10.1186/1744-859X-11-10

2) Grimholt, T. K., Haavet, O. R., Jacobsen, D., Sandvik, L., \& Ekeberg, O. (2014). Perceived competence and attitudes towards patients with suicidal behaviour: a survey of general practitioners, psychiatrists and internists. BMC Health Serv Res, 14, 208. doi:10.1186/1472-6963-14-208

\section{REFERANSER}

Beck, A. T., Steer, R. A., Beck, I. S., \& Newman, C. F. (1993). Hopelessness, depression, suicidal ideation, and clinical diagnosis of depression. Suicide Life Threat Behav, 23(2), 139-145. Retrieved from http://www.ncbi.nlm.nih.gov/pubmed/8342213

Beck, A. T., Weissman, A., Lester, D., \& Trexler, L. (1974). The measurement of pessimism: the hopelessness scale. I Consult Clin Psychol, 42(6), 861-865. Retrieved from http://www.ncbi.nlm.nih.gov/pubmed/4436473

Bergen, H., Hawton, K., Waters, K., Ness, I., Cooper, I., Steeg, S., \& Kapur, N. (2012). Premature death after self-harm: a multicentre cohort study. Lancet, 380(9853), 1568-1574. doi:10.1016/So140-6736(12)61141-6

Bjornaas, M. A., Hovda, K. E., Heyerdahl, F., Skog, K., Drottning, P., Opdahl, A., . Ekeberg, O. (2010). Suicidal intention, psychosocial factors and referral to further treatment: a one-year cross-sectional study of self-poisoning. BMC Psychiatry, 10, 58. doi:10.1186/1471-244X-10-58

Biornaas, M. A., Jacobsen, D., Haldorsen, T., \& Ekeberg, O. (2009). Mortality and causes of death after hospital-treated self-poisoning in Oslo: a 20 -year follow-up. Clin Toxicol (Phila), 47(2), 116-123. doi:10.1080/1556365070177198

Dieserud, G., Loeb, M., \& Ekeberg, O. (2000). Suicidal behavior in the municipality of Baerum, Norway: a 12-year prospective study of parasuicide and suicide. Suicide Life Threat Behav, 30(1), 61-73. Retrieved from http://www.ncbi.nlm.nih. gov/pubmed/10782719

Grimholt, T. K., Bjornaas, M. A., Jacobsen, D., Dieserud, G., \& Ekeberg, O. (2012). Treatment received, satisfaction with health care services, and psychiatric symptoms 3 months after hospitalization for self-poisoning. Ann Gen Psychiatry, 11, 10. doi:10.1186/1744-859X-11-10

Grimholt, T.K. (2007). Sykepleieres holdninger til pasienter etter selvmordsfor søk (Masteroppgave, Høgskolen i Oslo).

Grimholt, T. K., Haavet, O. R., Jacobsen, D., Sandvik, L., \& Ekeberg, O. (2014). Perceived competence and attitudes towards patients with suicidal behaviour: a survey of general practitioners, psychiatrists and internists. BMC Health Serv Res, 14, 208. doi:10.1186/1472-6963-14-208
Grimholt, T. K., Jacobsen, D., Haavet, O. R., Sandvik, L., Jorgensen, T., Norheim, A. B., \& Ekeberg, O. (2015). Structured follow-up by general practitioners after deliberate self-poisoning: a randomised controlled trial. BMC Psychiatry, 15, 245 doi:10.1186/s12888-015-0635-2

Hawton, K., Fagg, I., Platt, S., \& Hawkins, M. (1993). Factors associated with suicide after parasuicide in young people. BMI, 306(6893), 1641-1644. Retrieved from http://www.ncbi.nlm.nih.gov/pubmed/8324431

Heyerdahl, F., Biornaas, M. A., Dahl, R., Hovda, K. E., Nore, A. K., Ekeberg, O., \& Jacobsen, D. (2009). Repetition of acute poisoning in Oslo: 1-year prospective study. Br I Psychiatry, 194(1), 73-79. doi:10.1192/bip.bp.107.048322

Hvid, M., Vangborg, K., Sorensen, H. J., Nielsen, I. K., Stenborg, I. M., \& Wang, A G. (2011). Preventing repetition of attempted suicide--II. The Amager project, a randomized controlled trial. Nord I Psychiatry, 65(5), 292-298. doi:10.3109/0803 9488.2010 .544404

Kopiar, B., Dieserud, G., \& Wiik, I. (2005). [Deliberate self-poisonings treated in hospitals]. Tidsskr Nor Laegeforen, 125(13), 1798-1800. Retrieved from http:// www.ncbi.nlm.nih.gov/pubmed/16012544

Mork, E., Mehlum, L., Fadum, E. A., \& Rossow, I. (2010). Collaboration between general hospitals and community health services in the care of suicide attemp ters in Norway: a longitudinal study. Ann Gen Psychiatry, 9, 26. doi:10.1186/1744$859 X-9-26$

Norheim, A. B., Grimholt, T. K., \& Ekeberg, O. (2013). Attitudes towards suicidal behaviour in outpatient clinics among mental health professionals in Oslo. BMC Psychiatry, 13, 90. doi:10.1186/1471-244X-13-90

Runeson, B. (2001). Parasuicides without follow-up. Nord I Psychiatry, 55(5), 319 323. Retrieved from http://www.ncbi.nlm.nih.gov/pubmed/11839122

Samuelsson, M., Asberg, M., \& Gustavsson, I. P. (1997). Attitudes of psychiatric nursing personnel towards patients who have attempted suicide. Acta Psychi atr Scand, 95(3), 222-230. Retrieved from http://www.ncbi.nlm.nih.gov/pub$\mathrm{med} / 9111855$

Suokas, I., \& Lonnqvist, I. (1989). Work stress has negative effects on the atti tudes of emergency personnel towards patients who attempt suicide. Acta Psychiatr Scand, 79(5), 474-480. Retrieved from http://www.ncbi.nlm.nih.gov/ pubmed $/ 2750548$

Suokas, I., Suominen, K., \& Lonnqvist, I. (2008). Psychological distress and attitudes of emergency personnel towards suicide attempters. Nord I Psychiatry, 62(2), 144-146. doi:10.1080/08039480801983547

Suominen, K., Suokas, I., \& Lonnqvist, I. (2007). Attitudes of general hospital emergency room personnel towards attempted suicide patients. Nord I Psychiatry, 61(5), 387-392. doi:10.1080/08039480701643381

Taylor, T. L., Hawton, K., Fortune, S., \& Kapur, N. (2009). Attitudes towards clinical services among people who self-harm: systematic review. Br I Psychiatry, 194(2), 104-110. doi:10.1192/bip.bp.107.046425

Verwey, B., van Waarde, I. A., Bozdag, M. A., van Rooij, I., de Beurs, E., \& Zitman, F. G. (2010). Reassessment of suicide attempters at home, shortly after discharge from hospital. Crisis, 31(6), 303-310. doi:10.1027/0227-5910/a0ooo41

Wolk-Wasserman, D. (1985). The intensive care unit and the suicide attempt patient. Acta Psychiatr Scand, 71(6), 581-595. Retrieved from http://www.ncbi. nlm.nih.gov/pubmed/4024974

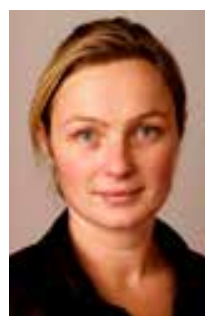

TINE K. GRIMHOLT er sykepleier og arbeider som postdoktorstipendiat ved Oslo universitetssykehus. Hun disputerte i 2015 på en doktoravhandling om fastlegers rolle etter selvpåført forgiftning: Self poisoning - studies of aftercare, attitudes, satisfaction and intervention. Postdoktor-prosjektet handler om barn som pårørende ved selvmordsatferd. 